\title{
Evaluation of soil properties in variously aged Scots pine plantations established on sandy soil
}

\author{
Peter Šurda ${ }^{1 *}$, L'ubomír Lichner ${ }^{1}$, Jozef Kollár ${ }^{2}$, Anton Zvala ${ }^{1}$, Dušan Igaz ${ }^{3}$ \\ ${ }^{1}$ Institute of Hydrology, Slovak Academy of Sciences, Dúbravská cesta 9, SK-84104 Bratislava, Slovakia. \\ ${ }^{2}$ Institute of Landscape Ecology, Slovak Academy of Sciences, Štefánikova 3, SK-81499 Bratislava, Slovakia. E-mail: j.kollar@savba.sk \\ ${ }^{3}$ Department of Biometeorology and Hydrology, Faculty of Horticulture and Landscape Engineering, Slovak University of Agriculture, Tr. \\ A. Hlinku 2, SK-94901 Nitra, Slovakia. \\ * Corresponding author. E-mail: surda@uh.savba.sk
}

\begin{abstract}
Pines are widely planted for sand dune stabilization and their cultivation results in the changes in physical, chemical, hydro-physical and water repellency properties. Soil properties were evaluated at three Scots pine plantations (PF1, PF2 and PF3) close to Studienka village, Borská nížina lowland (southwestern Slovakia) during hot and dry summer period. The PF1 site is a newly established plantation, the PF2 site is about 30 years old plantation, and the PF3 site is about 100 years old plantation. Here, we estimated the differences in $\mathrm{pH}$, soil organic carbon content, $\mathrm{C}_{\mathrm{ox}}$, particle size distribution, PSD, saturated, $k_{\mathrm{s}}$, and unsaturated, $k(-2 \mathrm{~cm})$, hydraulic conductivity, water, $S_{w}$, and ethanol, $S_{e}$, sorptivity, water drop penetration time, WDPT, and repellency index, RI. It was found that $\mathrm{C}_{\mathrm{ox}}$ varies most significantly with plantation age, and relative differences in PSD and $\mathrm{pH}$ were lower than the relative difference in $\mathrm{Cox}_{\mathrm{ox}}$ The PF3 site differs the most from the other two, especially in $\mathrm{C}_{\mathrm{ox}}$ and in the content of sand fraction. It can be attributed to the older age of the plantation, which represents a more advanced stage of succession accompanied by an accumulation of soil organic matter. Relationships between $\mathrm{C}_{\mathrm{ox}}, k(-2 \mathrm{~cm})$, RI, and WDPT and pine forest age were described by appropriate mathematical models. We found a similarity between $k(-2 \mathrm{~cm})$ and RI relationships vs. pine forest age (exponential models), and between $\mathrm{C}_{\mathrm{ox}}$ and WDPT relationships vs. pine forest age (first and second-order polynomial models). The latter similarity can be supported by the fact that soil water repellency is induced by the hydrophobic and amphiphilic components of soil organic matter.
\end{abstract}

Keywords: Sandy soil; Scots pine; Plantation; Forest restoration; Soil water repellency; Soil hydrophysical properties.

Abbreviations: MSP - mechanical site preparation, PSD - particle size distribution, RI - repellency index, SWR - soil water repellency, WDPT - water drop penetration time.

\section{INTRODUCTION}

Eolian (wind-blown) sand dunes form the central part of the Borská nížina lowland (southwestern Slovakia), which make it a specific region within Central Europe. Their origin dates back to the Pleistocene. The sand is siliceous and poor in nutrients and its thickness may reach as much as $30 \mathrm{~m}$ (Kalivodová et al., 2002). Despite Scots pine is being proven to be a native species here, its current large stands are intensively managed humanestablished plantations with specific undergrowth (Fig. 1a). Pines have been planted for sand dune stabilisation since the 18 th century. Nowadays, area of Scots pine plantations in the Borská nížina lowland exceeds 20000 ha (Krippel, 1965; Šomšák et al., 2003). Management of these plantations includes specific procedures. After reaching the maturity of the trees and clear cut logging of them, mechanical site preparation (MSP) for forest restoration is used (Sarvaš et al., 2007).

There are three main types of MSP for treatment of soils and vegetation: scarification, mounding, and subsoiling/ripping (Löf et al., 2012). Scarification or scuffing the soil, used in Borská nížina lowland, removes vegetation (moss and herb layer together with the seed bank) and the upper organic layers, which can be water repellent, and uncovers wettable bare soil (Sutton, 1993) having different chemical (soil organic carbon content, $\mathrm{C}_{\mathrm{ox}}, \mathrm{pH}$ ), physical (particle size distribution) and hydrophysical (hydraulic conductivity, sorptivity, water retention capacity) properties than the upper organic layer. MSP improves seedling survival and growth (Ahtikoski, 2010; Löf et al., 2006; Luoranen and Rikala, 2013), however, it leads to deep soil disturbance and loss of carbon from soil (Jandl et al., 2007). Restoration of the upper soil horizon can take a very long period and new plant communities must be developed in these places from the very beginning (Fig. 1b). According to Sarvaš et al. (2007) it is necessary to abandon MSP and replace it with technologies in which the stumps and roots will be crushed into smaller parts and left (scattered) on the surface, possibly incorporated into the soil and increasing $\mathrm{C}_{\mathrm{ox}}$.

Zema et al. (2021) presented the effects of black pine (Pinus nigra Arn subsp. salzmannii) forest ages on chemical, hydrophysical and water repellency properties of sandy clay loam soil. The persistence of water repellency was estimated by the water drop penetration time (WDPT) test. They found that soil $\mathrm{pH}$ decreased from 8.1 to 6.1 , hydraulic conductivity increased from 0.78 to $4.39 \mathrm{~mm} / \mathrm{hr}$, soil organic matter increased from 6.66 to $12.69 \%$, and WDPT (strangely) decreased from $55 \mathrm{~s}$ to $3 \mathrm{~s}$ in 1-19 years and 80-120 years old forests, respectively. The authors concluded that when a new forest stand is planted, decreases in water infiltration with subsequent increases in runoff can be expected. Conversely, no water repellency is likely to affect new black pine plantations due to the high (about 25\%) clay content of studied soil. 


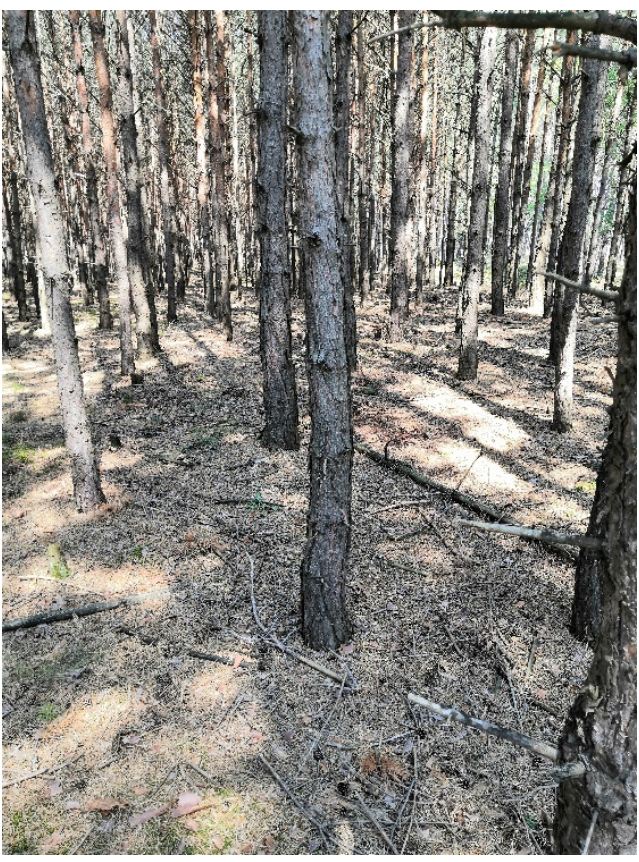

(a)

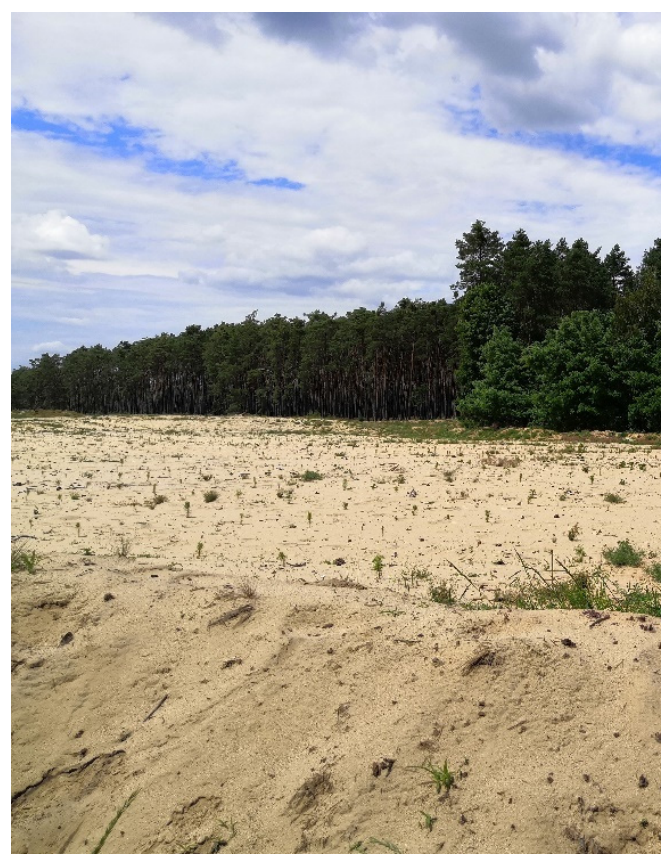

(b)

Fig. 1. (a) Cultivation of Scots pine forest on sand dune in Borská nížina lowland, Slovakia; (b) newly planted pine forest near Studienka, established using the technology of full-area mechanical site preparation (scarification of the soil).

Turfan et al. (2018) investigated the chemical compounds of ancient Anatolian black pine (Pinus nigra Arn subsp. pallasiana) needles from trees of different ages. Needles of over 500-, 200-, 100-, 50-, and 25-year-old black pine trees growing under similar environmental conditions were sampled and analysed for photosynthetic pigments (chlorophyll $a$, chlorophyll $b$ and carotenoids), proline, total soluble protein, glucose, sucrose, total soluble sugar, peroxidation level (MDAmalondialdehyde), hydrogen peroxide $\left(\mathrm{H}_{2} \mathrm{O}_{2}\right)$ and antioxidants such as ascorbate peroxidase (APX), catalase (CAT) and superoxide dismutase (SOD) activities. They found significant differences in chemical composition associated with age. Needles from over 500-year-old Anatolian black pine had the highest proline, total soluble protein, $\mathrm{H}_{2} \mathrm{O}_{2}$, sucrose, total soluble carbohydrates, APX, CAT and SOD concentrations, whereas they had the lowest chlorophyll $a$, total chlorophyll, total carotenoid and glucose concentrations. However, needles from 200-yearold trees had the highest glucose, but the lowest chlorophyll $b$, proline, $\mathrm{H}_{2} \mathrm{O}_{2}$ and total soluble carbohydrates. Needles from 50and 25-year-old trees together showed the highest chlorophyll $a$ and $b$, total chlorophyll, total carotenoid and MDA, but lowest total soluble protein and sucrose. Different chemical composition of needle litter can result in different chemical, hydrophysical and water repellency properties of soils under the trees.

Pine needles induced soil water repellency (SWR) in sandy soils is a dynamic property, varying temporally throughout the course of the year, being maximal in a hot and dry summer time (Buczko et al., 2005; Leelamanie and Nishiwaki, 2019; Lichner et al., 2013). SWR can increase the stability of soil aggregates (Fér et al., 2016; Goebel et al., 2005) and reduce soil water losses by evaporation (Lichner et al., 2020a; Rye and Smettem, 2017). On the other hand, SWR can decrease infiltration, and consequently diminish the groundwater level (Piyaruwan et al., 2020), increase runoff, soil erosion and surface water pollution (Diehl, 2013; Doerr et al., 2000). SWR can be alleviated by addition of lime (Roper, 2005), kaolinite clay (Lichner et al., 2002; McKissock et al., 2000), and wax degrading bacteria (Roper, 2006). The differences in water repellency among the soils under different types of vegetation can be ascribed to differences in carbon content and, especially, in $\mathrm{C} / \mathrm{N}$ ratio (Benito et al., 2019).

The main objective of the research was to evaluate the chemical $\left(\mathrm{pH}, \mathrm{C}_{\mathrm{ox}}\right)$, physical (particle size distribution), hydrophysical $\left(k_{s}, k(-2 \mathrm{~cm}), S_{w}, S_{e}\right)$ and water repellency (WDPT, RI) properties of sandy soil in variously aged Scots pine plantations during hot and dry summer period. Determination of the appropriate mathematical models of the relationships between organic carbon content, hydraulic conductivity, water repellency parameters and pine forest age was another objective of this research.

\section{MATERIAL AND METHODS}

Study sites

The experimental area is located at hunting lodge Kudelka near Studienka village $\left(48^{\circ} 31.733^{\prime} \mathrm{N}, 1^{\circ} 07.315^{\prime} \mathrm{E}\right)$ in the Borská nížina lowland (southwestern Slovakia). According to the Köppen-Geiger climate classification, the region has temperate climate without dry season, warm summer $(\mathrm{Cfb})$ (Kottek et al., 2006), with mean annual air temperature of $9.5^{\circ} \mathrm{C}$. Mean annual precipitation is about $550 \mathrm{~mm}$, which is mainly summerdominant.

Three study sites PF1, PF2 and PF3 (separated by the distance of about $800 \mathrm{~m}$ ) were chosen to include three phases of Scots pine plantation development. The soils of all the sites are classified as Arenosol (WRB, 2014) and have sandy texture (Soil Survey Division Staff, 1993). Plant nomenclature follows Marhold and Hindák (1998).

The site PF1 is a newly established plantation of Scots pine (Pinus sylvestris L.) on bare sand without any vegetation, because the surface soil layer was removed before plantation. 
The site PF2 is about 30 years old Scots pine plantation. Tree layer is very dense with no undergrowth. Soil surface is covered by several centimetres thick layer of needle litter. Prior to the stand plantation, the surface soil layer with a humus horizon was removed, so trees were planted in bare sand.

The site PF3 is over 100 years old the Scots pine forest established to stabilise sandy dune. The tree layer cover is about $60 \%$ and shrub layer is missing. The cover of herb layer is about $30 \%$. It is dominated by grass Festuca ovina agg. L. and Calamagrostis epigejos (L.) Roth is also common here. Other species are only admixed, such as Hieracium murorum L., weedy species Solanum nigrum L., and allochthonous species with invasive behaviour, such as Phytolacca americana L., Prunus serotina Ehrh. and Conyza canadensis (L.) Cronq. The layer of cryptogram is conspicuously well developed; its cover is over $90 \%$. It is dominated by Pleurozium schreberi (Bird.) Mitt., which is accompanied by Dicranum polysetum Sw. ex anon. and Pseudoscleropodium purum (Hedw.) M.Fleisch., 1923. Surface layers of 3 study sites PF1, PF2 and PF3 are shown in Fig. 2.

\section{Laboratory methods}

The soil sampling was conducted in July 2020. The disturbed soil samples for determination of basic soil properties at the experimental sites PF1, PF2 and PF3 were taken in the surface $(0-10 \mathrm{~cm})$ layer, after the fresh litter from the soil surface was removed. Similarly, two undisturbed soil cores with a volume of $100 \mathrm{~cm}^{3}$ were taken at each site in the depths of $0-5$ $\mathrm{cm}$ or $2-7 \mathrm{~cm}$ on levelled ground for determination of saturated hydraulic conductivity. The cores were sampled using a standard coring device. The soil sampling was performed on an area of $2 \mathrm{~m} \mathrm{x} 2 \mathrm{~m}$, in a distance of about $50 \mathrm{~cm}$ from the nearest tree and of about $2 \mathrm{~m}$ from the area of infiltration experiments.

Basic soil properties were determined with three replications in the ISO Certified Laboratory of the Soil Science and Protection Research Institute in Bratislava. Particle size distribution was determined by sieving and sedimentation according to ISO 11277 (2009), $\mathrm{pH}(\mathrm{KCl})$ and $\mathrm{pH}\left(\mathrm{H}_{2} 0\right)$ were measured according to ISO 10390 (2005), $\mathrm{C}_{\mathrm{ox}}$ content was determined by oxidation with $\mathrm{K}_{2} \mathrm{Cr}_{2} \mathrm{O}_{7}-\mathrm{H}_{2} \mathrm{SO}_{4}$ and titration of non-reduced dichromate according to ISO 10694 (1995), and carbonate content was determined from the volume of $\mathrm{CO}_{2}$, produced during the decomposition of carbonates with about $10 \%$ hydrochloric acid, according to ISO 10693 (1995).

The saturated hydraulic conductivity was measured in the laboratory using the falling head method (Reynolds et al.,
2002). Before the measurement, the undisturbed soil samples were saturated from below in a water tank. SWR can disappear after a sufficiently long exposure to soil moisture, and therefore, the samples from site PF1 have been saturated for 2 weeks and samples from site PF2 and PF3 for 6 weeks.

\section{Field methods}

All field experiments at the experimental sites PF1, PF2 and PF3 were performed on an area of $4 \mathrm{~m} \times 4 \mathrm{~m}$, in a distance of about $50 \mathrm{~cm}$ from the nearest tree and of about $2 \mathrm{~m}$ from the area of soil sampling. The number $N$ of replicates of each measurement is presented in Table 2 .

The volumetric soil water content $\theta\left(\mathrm{m}^{3} \mathrm{~m}^{-3}\right)$ of the superficial $(0-10 \mathrm{~cm})$ soil layer was measured with the moisture meter HH2 and soil moisture sensor SM200 (Delta-T Devices Ltd., Cambridge, UK).

Field measurements of infiltration were performed using the minidisk infiltrometer $(4.5 \mathrm{~cm}$ in diameter) under a negative tension $h_{0}=-2 \mathrm{~cm}$ (Alagna et al., 2017, 2019). Prior to the measurements, the litter layer was removed gently to prevent disturbance of the mineral soil. The cumulative infiltration $I$ was calculated based on the Philip infiltration equation:

$I=C_{1} t^{1 / 2}+C_{2} t+C_{3} t^{3 / 2}+\ldots+C_{m} t^{\mathrm{m} / 2}+\ldots$

where $C_{1}, C_{2}, C_{3}, \ldots$, and $\mathrm{C}_{m}$ are coefficients, and $t$ is time.

The sorptivity, $S(-2 \mathrm{~cm})$, was estimated from the first term of the Philip infiltration equation $\left(I=C_{l} t^{1 / 2}\right)$ during early-time infiltration (60-180 s) of water and ethanol (Clothier et al., 2000):

$S\left(h_{0}\right)=I / t^{1 / 2}$

Equation (2) was used to calculate the sorptivity of both water, $S_{w}(-2 \mathrm{~cm})$, and ethanol, $S_{e}(-2 \mathrm{~cm})$, from the cumulative infiltration $v s$. time relationships taken from the minidisk infiltrometer measurements. It was found that $S_{w}$ is not function of water source tension, but is function of initial soil water content. The highest value of $S_{w}$ corresponded to the lowest soil water content, remaining practically constant in a large range of soil water content, and abruptly decreasing near saturation toward zero (Villarreal et al., 2019). It should be mentioned that the water sorptivity is a measure of both the SWR and soil pore size, while the ethanol sorptivity is a measure of soil pore size only.

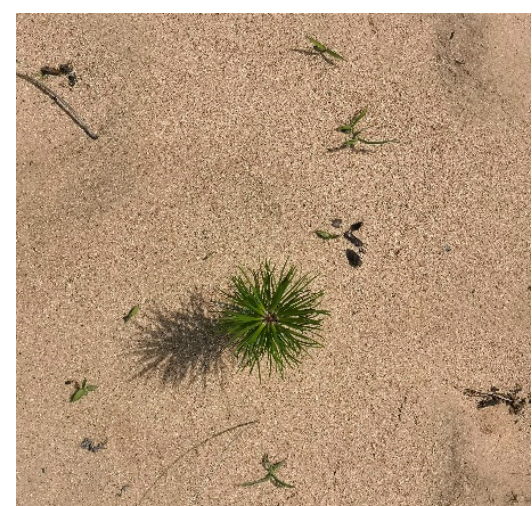

a

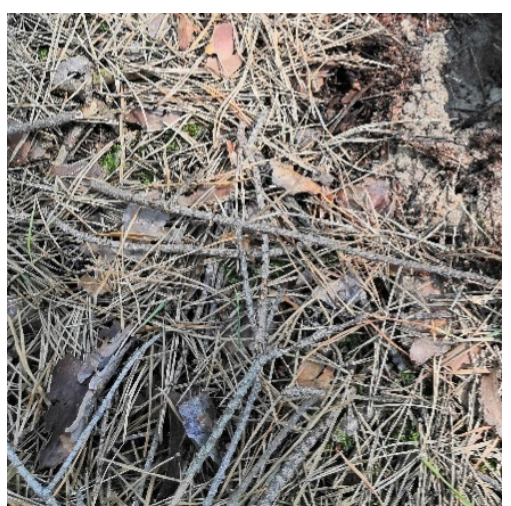

b

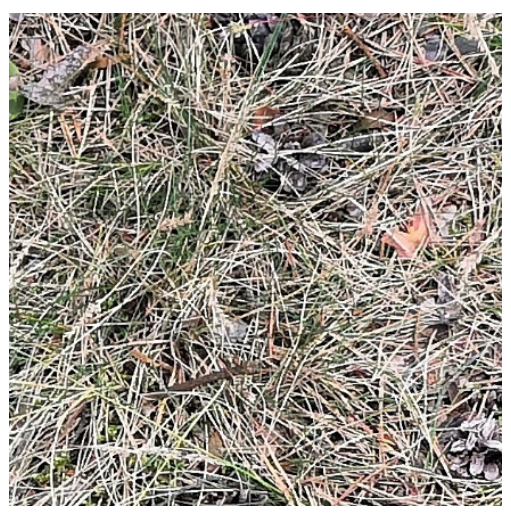

C

Fig. 2. Surface layers of a) PF1 - a newly established plantation of Scots pine; b) PF2 - 30 years old Scots pine plantation; c) PF3 - over 100 years old Scots pine (Pinus sylvestris L.) plantation. 
Zhang (1997) proposed to use first two terms of the Philip infiltration equation to fit the cumulative infiltration $v s$. time relationship and estimate the hydraulic conductivity $k\left(h_{0}\right)$ :

$k\left(h_{0}\right)=C_{2} / A$

where $A$ is a dimensionless coefficient. Equation (3) was used to estimate the hydraulic conductivity $k(-2 \mathrm{~cm})$ in this study, using $A=1.7279$ for sandy soil and suction $h_{0}=-2 \mathrm{~cm}$ from the Minidisk Infiltrometer User's Manual (Decagon, 2007).

The repellency index RI (Hallett and Young, 1999; Lichner et al., 2020b):

$\mathrm{RI}=1.95 S_{e}(-2 \mathrm{~cm}) / S_{w}(-2 \mathrm{~cm})$

was estimated from the combination of all the ethanol and water sorptivities, i.e., $\mathrm{m} \times \mathrm{n}$ values of RI were calculated from $\mathrm{m}$ values of $S_{w}(-2 \mathrm{~cm})$ and n values of $S_{e}(-2 \mathrm{~cm})$ (Pekárová et al., 2015). The following classes of the extent of SWR were distinguished: wettable or non-water-repellent soil $(\mathrm{RI}<1.95)$, slightly $(\mathrm{RI}=1.95-10)$, strongly $(\mathrm{RI}=10-50)$, severely $(\mathrm{RI}=$ $50-110)$, and extremely (RI $>110$ ) water repellent soil (Iovino et al., 2018).

The persistence of soil water repellency was estimated with water drop penetration time (WDPT) test. The WDPT test involves placing of one $58 \pm 5 \mu \mathrm{L}$ drop of water from a medicine dropper on a soil from a standard height of $10 \mathrm{~mm}$ above the surface and recording the time taken for its complete penetration. A standard droplet release height of approximately 10 $\mathrm{mm}$ above the soil surface was used to minimize the cratering effect on the soil surface (Doerr, 1998; Tinebra et al., 2019). Ten replicates of WDPT test were undertaken for each site, and the arithmetic mean was used for WDPT classification. The following classes of the persistence of SWR were then distinguished: wettable or non-water-repellent soil (WDPT $<5$ s), slightly $(\mathrm{WDPT}=5-60 \mathrm{~s})$, strongly $(\mathrm{WDPT}=60-600 \mathrm{~s})$, severely $($ WDPT $=600-3600 \mathrm{~s})$, and extremely $(\mathrm{WDPT}>3600 \mathrm{~s})$ water repellent soil (Bisdom et al., 1993).

\section{Statistical analysis}

Differences between the parameters estimated in different sites were evaluated using single factor ANOVA with Tukey's Honest Significant Difference (HSD) post-hoc test. The TukeyKramer method (also known as Tukey's HSD method) uses the Studentized Range distribution to compute the adjustment to the critical value. The Tukey-Kramer method achieves the exact alpha level (and simultaneous confidence level $(1-\alpha)$ ) if the group sample sizes are equal and is conservative if the sample sizes are unequal. The statistical significance in the analysis was defined at $\mathrm{P}<0.05$.

NCSS 12 Statistical Software (2018) was used to determine an appropriate mathematical models (among preprogrammed
39 models), representing relationships between a dependent (hydrophysical and water repellency parameters) and a single independent variable (age of pine forest) and to estimate the values of its parameters using nonlinear regression. Two methods are used to calculate confidence intervals of the regression parameters and predicted values. The first method is based on the usual normality and constant variance of residuals assumption. When the data follow these assumptions, standard expressions for the confidence intervals are used based on the Student's $t$ distribution. The second method is called the bootstrap method. Bootstrapping provides standard errors and confidence intervals for nonlinear-regression parameter, predicted means, and predicted values. Bootstrap confidence intervals are based on the assumption that your sample is actually representative of the population. Beginning with this assumption, $\mathrm{B}$ samples are drawn ( $\mathrm{B}$ is over 1000) of size $\mathrm{N}$ from your original sample with replacement. Sampling with replacement means that each observation may be selected more than once. For each bootstrap sample, the nonlinear-regression results are computed and stored (NCSS 12 Statistical Software, 2018).

Each dataset was fitted with all 39 models and the most appropriate model was selected according to the highest value of the coefficient of determination $\left(\mathrm{R}^{2}\right)$, which is statistical measure of how well the regression model fits the data. $\mathrm{R}^{2}$ may be defined either as a ratio or a percentage. Since we use the ratio form, its values range from zero to one. A value of $\mathrm{R}^{2}$ near zero indicates no linear relationship between the $\mathrm{Y}$ and the $\mathrm{X}$ 's, while a value near one indicates a perfect fit.

\section{RESULTS AND DISCUSSION}

Physical and chemical properties of the top soil $(0-10 \mathrm{~cm})$, measured from disturbed samples taken from the experimental sites are presented in Table 1. Classification of the soil texture is the same for all 3 study sites (sand texture class), however, the particle size distribution (PSD) shows some differences. Proportion of the coarsest grain fraction is decreasing in the order $\mathrm{PF} 1>\mathrm{PF} 2>\mathrm{PF} 3$, while the fine-grained fraction has an increasing trend. Proportion of all grain size fractions at PF3 site is significantly different from the other two sites. A decrease in the proportion of coarse-grained particles (Fig. 3a) is associated with an increase in the organic carbon content $\left(\mathrm{C}_{\mathrm{ox}}\right)$ (Fig. 3b) at study sites in order PF $1<\mathrm{PF} 2<\mathrm{PF} 3$. Statistically, all three study sites are significantly different from each other, however while the PF1 and PF2 have very low values of $\mathrm{C}_{\mathrm{ox}}$, value of $\mathrm{C}_{\mathrm{ox}}$ at PF3 is very high. Together with the $\mathrm{C}_{\mathrm{ox}}$, the thickness of organic layer is also increasing in the upper part of soil profiles in order $\mathrm{PF} 1<\mathrm{PF} 2<\mathrm{PF} 3$. The value of $\mathrm{pH}$ at all study sites (Fig 3c) is evaluated as extremely acidic; the trend of $\mathrm{pH}$ is slightly decreasing in order PF1 $>\mathrm{PF} 2>\mathrm{PF} 3$. Study site $\mathrm{PF} 3$ is significantly different from $\mathrm{PF} 1$ and $\mathrm{PF} 2$ in $\mathrm{pH}$ value, similarly to the PSD.

Table 1. Physical and chemical properties ( \pm their standard deviation) of the top $(0-10 \mathrm{~cm})$ soils taken from the experimental sites $P F 1$, PF2 and PF3 near Studienka. (TOL - thickness of organic layer, $\mathrm{C}_{\mathrm{ox}}-$ soil organic carbon content). Arithmetic means with the same letter are not significantly different from each other (Tukey's HSD test, $\mathrm{P}<0.05$ ).

\begin{tabular}{|c|c|c|c|c|c|c|}
\hline Site & $\begin{array}{l}\text { Sand } \\
(\%)\end{array}$ & $\begin{array}{l}\text { Silt } \\
(\%)\end{array}$ & $\begin{array}{l}\text { Clay } \\
(\%)\end{array}$ & $\begin{array}{l}\text { TOL } \\
(\mathrm{cm})\end{array}$ & $\begin{array}{l}\mathrm{C}_{\mathrm{ox}} \\
(\%)\end{array}$ & $\begin{array}{l}\mathrm{pH} \\
\left(\mathrm{H}_{2} \mathrm{O}\right)\end{array}$ \\
\hline PF1 & $\begin{array}{r}97.07^{\mathrm{a}} \pm 0.12 \\
\text { te }\end{array}$ & $\begin{array}{r}1.41^{\mathrm{a}} \pm 0.10 \\
\text { sture class: sa }\end{array}$ & $d .48^{a} \pm 0.17$ & 0 & $\begin{array}{l}0.11^{\mathrm{a}} \pm 0.01 \\
\text { very low }\end{array}$ & $\begin{array}{c}4.36^{\mathrm{a}} \pm 0.30 \quad 4.10^{\mathrm{a}} \pm 0.04 \\
\text { extremely acidic }\end{array}$ \\
\hline PF2 & $\begin{array}{r}96.27^{\mathrm{a}} \pm 0.42 \\
\text { te }\end{array}$ & $\begin{array}{r}2.53^{\mathrm{a}} \pm 0.99 \\
\text { sture class: sa }\end{array}$ & $d^{1.20^{\mathrm{a}} \pm 0.70}$ & $6 \pm 2$ & $\begin{array}{l}0.44^{\mathrm{b}} \pm 0.01 \\
\text { very low }\end{array}$ & $\begin{array}{c}4.23^{\mathrm{a}} \pm 0.10 \quad 3.88^{\mathrm{a}} \pm 0.03 \\
\text { extremely acidic }\end{array}$ \\
\hline PF3 & $\begin{array}{r}89.90^{\mathrm{b}} \pm 1.73 \\
\text { te }\end{array}$ & $\begin{array}{r}5.79^{\mathrm{b}} \pm 1.29 \\
\text { ture class: sa }\end{array}$ & $4.31^{b} \pm 0.45$ & $20 \pm 3$ & $\begin{array}{l}3.83^{\mathrm{c}} \pm 0.21 \\
\text { very high }\end{array}$ & $\begin{array}{c}3.79^{\mathrm{b}} \pm 0.18 \quad 3.09^{\mathrm{b}} \pm 0.05 \\
\text { extremely acidic }\end{array}$ \\
\hline
\end{tabular}


(a)

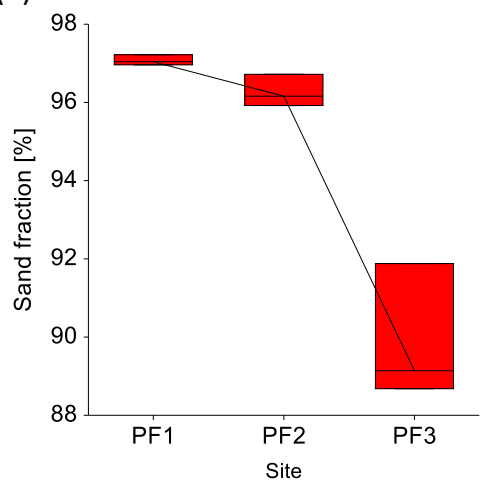

(b)

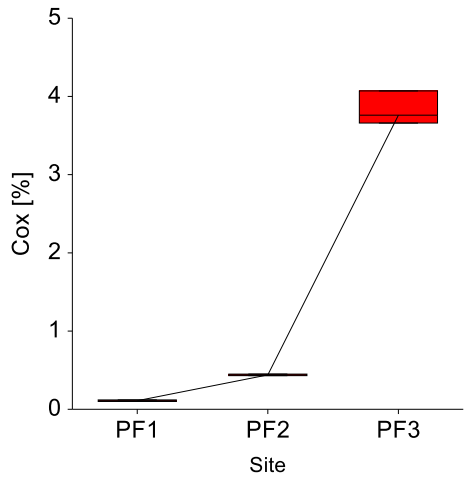

(c)

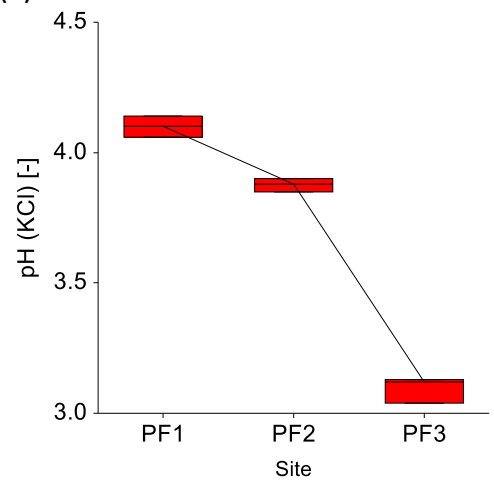

Fig. 3. Box plots of selected physical and chemical properties - (a) sand fraction, (b) soil organic carbon content $\mathrm{C}_{\mathrm{ox}},(\mathrm{c}) \mathrm{pH}(\mathrm{KCl})$, measured at study sites PF1, PF2 and PF3 near Studienka, Slovakia.

According to the evaluation of physical and chemical properties of the soils at study sites, we can summarize that the value of $\mathrm{C}_{\text {ox }}$ varies most significantly (all sites show a significant difference in $\mathrm{Cox}_{\mathrm{ox}}$; to a lesser extent we found a difference also in the PSD and $\mathrm{pH}$. The PF3 site differs the most from two other sites, especially in $\mathrm{C}_{\mathrm{ox}}$ and in the content of sand fraction. It can be attributed to the older age of the plantation, which represents a more advanced stage of succession accompanied by an accumulation of an organic matter.

All laboratory and field measurements of the soil hydrophysical and water repellency properties were conducted in June 2020. The values of soil water content, $\theta\left(\mathrm{m}^{3} \mathrm{~m}^{-3}\right)$, in upper $10 \mathrm{~cm}$ of soil profile, saturated hydraulic conductivity, $k \mathrm{~s}$, unsaturated hydraulic conductivity, $k(-2 \mathrm{~cm})$, sorptivity of both water, $S_{w}(-2 \mathrm{~cm})$, and ethanol, $S_{e}(-2 \mathrm{~cm})$, repellency index, RI, and water drop penetration time, WDPT, are shown in Table 2. Long hot and dry spell in the time of measurements and sampling, resulted in a small volumetric soil water content $(\theta=0.02,0.05,0.06)$ at all sites. The values of $\theta$ were minimal at all sites, but newly established plantation PF1 has even lower $\theta$, significantly different from $\mathrm{PF} 2 / \mathrm{PF} 3$. Saturated hydraulic conductivity $\left(k_{\mathrm{s}}\right)$, has a slightly decreasing trend in order PF1 $>$ PF2 $>$ PF3 (Fig. 4a). Significantly different are only $k_{\text {s }}$ from sites PF1 and PF3. It is necessary to note that $k_{\mathrm{s}}$ was measured after saturation of the samples i.e., without the effect of SWR. Unsaturated hydraulic conductivity $k(-2 \mathrm{~cm})$ has also a declining trend in order $\mathrm{PF} 1>\mathrm{PF} 2>\mathrm{PF} 3$ (Fig. $4 \mathrm{~b}$ ), but significant differences are only between PF1 and PF2/PF3. It is caused by the elimination of SWR on PF1 and recovered SWR on PF2 and PF3. Sorptivity of ethanol has slightly declining trend (Fig. 4d), with significant difference between PF1 and PF2/PF3. Sorptivity of water has obvious decreasing trend between PF1 and PF2 and a less steep decrease between PF2 and PF3 (Fig. $4 \mathrm{c})$, which is similar to $k(-2 \mathrm{~cm})$. Significant differences are between PF1 and PF2/PF3.

It was determined from the arithmetic means of WDPT in Table 2 that soil at PF1 is slightly water repellent, soil at PF2 severely and soil at PF3 extremely water repellent. It follows from the arithmetic means of RI in Table 2 that soil at PF1 is wettable/non-water-repellent, and soils at PF2 and PF3 are severely water-repellent. SWR parameters have an obviously increasing trend in order $\mathrm{PF} 1<\mathrm{PF} 2<\mathrm{PF} 3$ (Figs. $4 \mathrm{e}, 4 \mathrm{f}$ ), but there are statistical differences between parameters RI and WDPT. RI shows a significant difference between PF1 and PF2/PF3, but not significant difference between PF2 and PF3. On the contrary, WDPT showed a statistically significant difference between $\mathrm{PF} 1 / \mathrm{PF} 2$ and $\mathrm{PF} 3$, but not significant difference between PF1 and PF2.

Analysis of physical, hydrophysical and water repellency parameters allows us to summarize the obtained results. There is an evident increase in water repellency parameters at study sites in order $\mathrm{PF} 1<\mathrm{PF} 2<\mathrm{PF} 3$, with different performance of parameters WDPT and RI. Similar increase in WDPT with Scots pine forest age presented Hewelke et al. (2018). SWR was induced by the litter and vegetation cover (pine needles at PF2 and grass cover/pine needles at PF3). Increase in SWR (and also the increase of $\left.\mathrm{C}_{\mathrm{ox}}\right)$ can be related with the decline of $k(-2 \mathrm{~cm}), S_{\mathrm{w}}$ and $S_{\mathrm{e}}$. The values of $k_{\mathrm{s}}$ also decreased at sites PF2 and PF3, but we assume that it was due to an increase in $\mathrm{C}_{\mathrm{ox}}$ and fine (silt and clay) soil fraction. Increase in $\mathrm{Cox}_{\mathrm{x}}$ and WDPT with time was registered also in our former studies of primary (Lichner et al., 2018; Šurda et al., 2015) and secondary (Lichner et al., 2020b) succession in this region. The SWR - Cox relation can be supported by the fact that SWR is induced by the hydrophobic and amphiphilic components of soil organic matter. Some authors (e.g., Buczko et al., 2002; Hrabovský et al., 2020; Zavala et al., 2009) found positive correlation between SWR and soil organic matter; other authors shown that quantity of soil organic matter alone could not fully explain the increase of SWR (Zema et al., 2021). Dinel et al. (1990) found that the concentration of hydrophobic lipid compounds decreases with increasing efficiency of organic matter decomposition and Cesarano et al. (2016) shown that litter incorporated into the soil can produce a variety of effects on SWR, ranging from a dramatic increase to a null effect depending on the considered litter type.

Very slight decrease in $\mathrm{pH}$ is consistent with Achilles et al. (2021), who observed acidification of the mineral soil (up to 0.5 $\mathrm{pH}$ units) in coniferous stand (mixture of Norway spruce and Scots pine) in central Germany, which was linked to the fine root distribution and the cation uptake. The greatest acidification occurred in the topsoil at a depth of $0-10 \mathrm{~cm}$. For this depth, Bolte and Villanueva (2005) reported the highest amounts of living fine root biomass.

We tried to find appropriate mathematical models of the relationships between $\mathrm{Cox}_{\mathrm{ox}}, k(-2 \mathrm{~cm}), \mathrm{RI}$, and WDPT and pine forest age. The relationship of $\mathrm{C}_{\mathrm{ox}}$ vs. pine forest age (Fig. 5a) was described by the first-order polynomial model with $\mathrm{R}^{2}=$ 0.996 . The relationship of $k(-2 \mathrm{~cm})$ over time was described by the three-parameter logistic model (Fig. 5b) with $\mathrm{R}^{2}=0.764$. The relationship of WDPT vs. pine forest age was described by the second-order polynomial model (Fig. $5 \mathrm{c}$ ) with $\mathrm{R}^{2}=0.792$. 
Table 2. Soil water content, $\theta$, saturated hydraulic conductivity, $k_{\mathrm{s}}$, unsaturated hydraulic conductivity, $k(-2 \mathrm{~cm})$, sorptivity of water, $S_{w}(-2 \mathrm{~cm})$, and ethanol, $S_{e}(-2 \mathrm{~cm})$, repellency index, RI, and water drop penetration time, WDPT, at the sites PF1, PF2 and PF3 near Studienka. $N$ is the number of replicates of each measurement. Arithmetic means with the same letter are not significantly different from each other (Tukey's HSD test, $\mathrm{P}<0.05$ ).

\begin{tabular}{|c|c|c|c|c|c|c|c|c|}
\hline Site & Attribute & Minimum & Maximum & Arithmetic mean & Standard deviation & Skewness & Kurtosis & $N$ \\
\hline \multirow[t]{7}{*}{ PF1 } & $\theta\left(\mathrm{m}^{3} \mathrm{~m}^{-3}\right)$ & 0.010 & 0.033 & $0.020^{\mathrm{a}}$ & 0.007 & 0.446 & 2.842 & 10 \\
\hline & $k_{s}\left(\mathrm{~cm} \mathrm{~s}^{-1}\right)$ & 0.012 & 0.014 & $0.0130^{\mathrm{a}}$ & $9.97 \times 10^{-4}$ & - & - & 2 \\
\hline & $k(-2 \mathrm{~cm})\left(\mathrm{cm} \mathrm{s}^{-1}\right)$ & 0.0126 & 0.0363 & $0.0193^{\mathrm{a}}$ & 0.0098 & 1.302 & 2.957 & 5 \\
\hline & $S_{w}(-2 \mathrm{~cm})\left(\mathrm{cm} \mathrm{s}^{-1 / 2}\right)$ & 0.1097 & 0.1245 & $0.1174^{\mathrm{a}}$ & 0.0066 & 0.096 & 1.373 & 5 \\
\hline & $S_{e}(-2 \mathrm{~cm})\left(\mathrm{cm} \mathrm{s}^{-1 / 2}\right)$ & 0.1055 & 0.110 & $0.1084^{\mathrm{a}}$ & 0.0025 & -0.703 & 1.50 & 3 \\
\hline & $\mathrm{RI}(-)$ & 1.653 & 1.956 & $1.807^{\mathrm{a}}$ & 0.0998 & -0.027 & 1.752 & 15 \\
\hline & WDPT (s) & 1 & 99 & $44^{\mathrm{a}}$ & 35.292 & 0.316 & 2.029 & 10 \\
\hline \multirow[t]{7}{*}{ PF2 } & $\theta\left(\mathrm{m}^{3} \mathrm{~m}^{-3}\right)$ & 0.034 & 0.089 & $0.052^{\mathrm{b}}$ & 0.019 & 1.011 & 2.657 & 10 \\
\hline & $k_{s}\left(\mathrm{~cm} \mathrm{~s}^{-1}\right)$ & 0.009 & 0.010 & $0.0098^{\mathrm{a}, \mathrm{b}}$ & $6.36 \times 10^{-4}$ & - & - & 2 \\
\hline & $k(-2 \mathrm{~cm})\left(\mathrm{cm} \mathrm{s}^{-1}\right)$ & $2.25 \times 10^{-6}$ & $6.58 \times 10^{-5}$ & $1.98 \times 10^{-5 b}$ & $2.60 \times 10^{-5}$ & 1.423 & 3.157 & 5 \\
\hline & $S_{w}(-2 \mathrm{~cm})\left(\mathrm{cm} \mathrm{s}^{-1 / 2}\right)$ & 0.0021 & 0.0036 & $0.00295^{b}$ & $5.80 \times 10^{-4}$ & -0.337 & 2.041 & 5 \\
\hline & $S_{e}(-2 \mathrm{~cm})\left(\mathrm{cm} \mathrm{s}^{-1 / 2}\right)$ & 0.0692 & 0.0991 & $0.07886^{b}$ & 0.0128 & 0.870 & 2.15 & 5 \\
\hline & $\mathrm{RI}(-)$ & 37.071 & 91.576 & $53.962^{b}$ & 13.5130 & 0.969 & 3.595 & 25 \\
\hline & WDPT (s) & 854 & 6805 & $2543.2^{\mathrm{a}}$ & 2267.570 & 1.210 & 2.742 & 10 \\
\hline \multirow[t]{7}{*}{ PF3 } & $\theta\left(\mathrm{m}^{3} \mathrm{~m}^{-3}\right)$ & 0.030 & 0.117 & $0.063^{\mathrm{b}}$ & 0.025 & 0.847 & 3.486 & 10 \\
\hline & $k_{s}\left(\mathrm{~cm} \mathrm{~s}^{-1}\right)$ & 0.006 & 0.007 & $0.0063^{b}$ & $1.20 \times 10^{-3}$ & - & - & 2 \\
\hline & $k(-2 \mathrm{~cm})\left(\mathrm{cm} \mathrm{s}^{-1}\right)$ & $8.89 \times 10^{-6}$ & $2.05 \times 10^{-5}$ & $1.17 \times 10^{-5 b}$ & $4.93 \times 10^{-6}$ & 1.443 & 3.174 & 5 \\
\hline & $S_{w}(-2 \mathrm{~cm})\left(\mathrm{cm} \mathrm{s}^{-1 / 2}\right)$ & 0.0018 & 0.0032 & $0.0025^{b}$ & $5.99 \times 10^{-4}$ & 0.008 & 1.483 & 5 \\
\hline & $S_{e}(-2 \mathrm{~cm})\left(\mathrm{cm} \mathrm{s}^{-1 / 2}\right)$ & 0.0610 & 0.0910 & $0.0726^{b}$ & 0.0142 & 0.469 & 1.60 & 4 \\
\hline & $\mathrm{RI}(-)$ & 36.720 & 98.311 & $58.363^{\mathrm{b}}$ & 16.7393 & 0.686 & 2.855 & 20 \\
\hline & WDPT (s) & 6670 & 23040 & $14396.2^{b}$ & 5397.674 & 0.110 & 1.870 & 10 \\
\hline
\end{tabular}

(a)

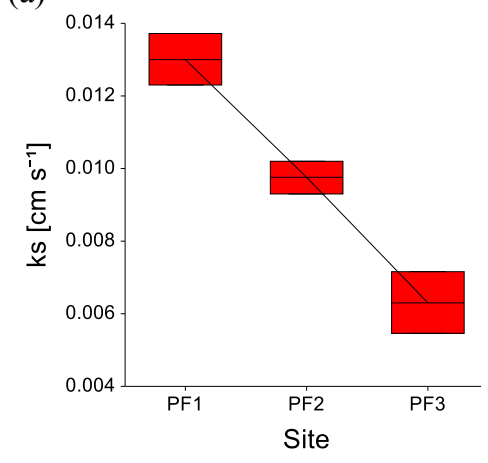

(d)

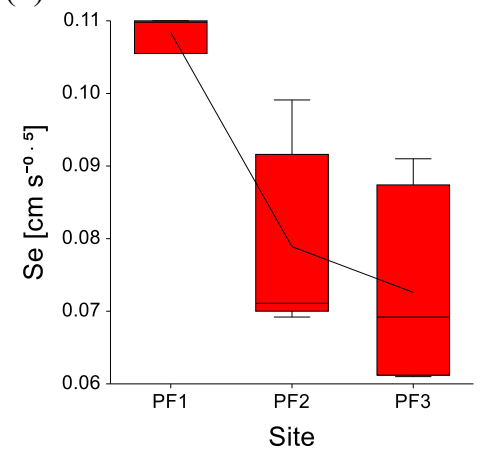

(b)

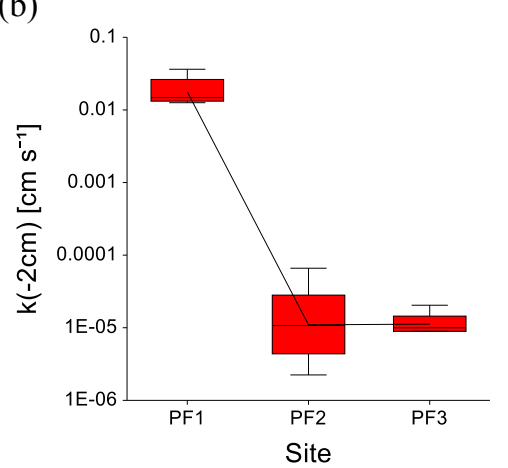

(e)

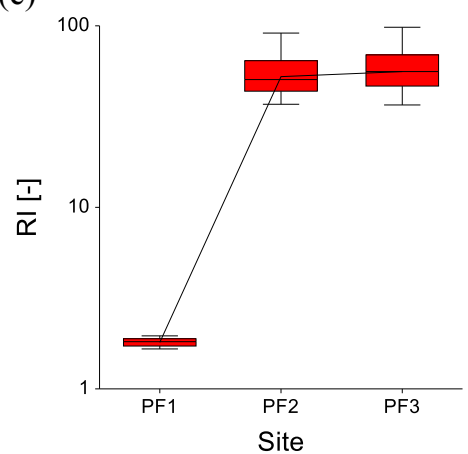

(c)

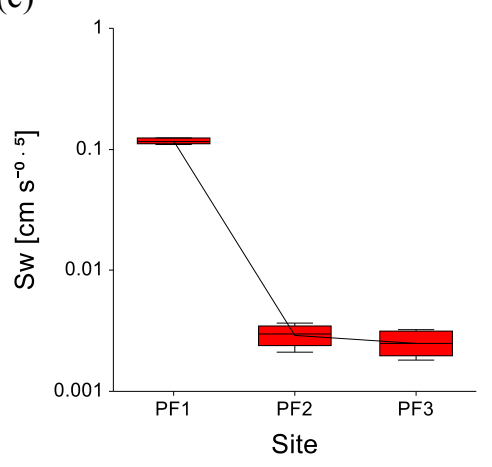

(f)

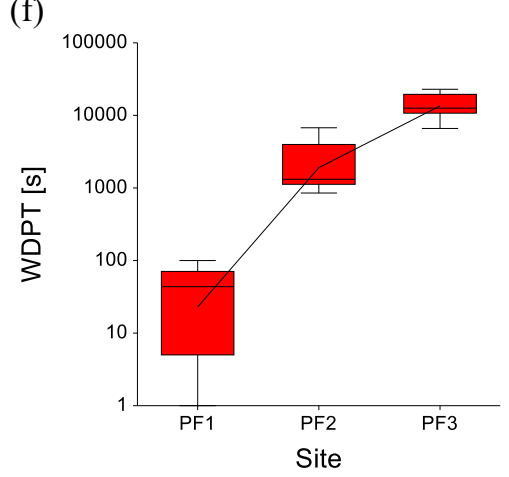

Fig. 4. Box plots of selected hydrophysical and repellency parameters: (a) saturated hydraulic conductivity $k_{\mathrm{s}}$, (b) hydraulic conductivity $k(-2 \mathrm{~cm})$, (c) water sorptivity $S_{\mathrm{w}}(-2 \mathrm{~cm})$, (d) ethanol sorptivity $S_{\mathrm{e}}(-2 \mathrm{~cm})$, (e) repellency index RI, (f) water drop penetration time WDPT, measured at study site PF1, PF2 and PF3 in Borská nížina lowland (southwestern Slovakia).

The relationship of RI vs. pine forest age was expressed by the monomolecular model (Fig. 5d) with $\mathrm{R}^{2}=0.798$. When we compared the obtained mathematical models, we found a simi- larity between $k(-2 \mathrm{~cm})$ and RI relationships vs. pine forest age (exponential models), and between $\mathrm{C}_{\mathrm{ox}}$ and WDPT relationships vs. pine forest age (first and second-order polynomial models). 
(a)

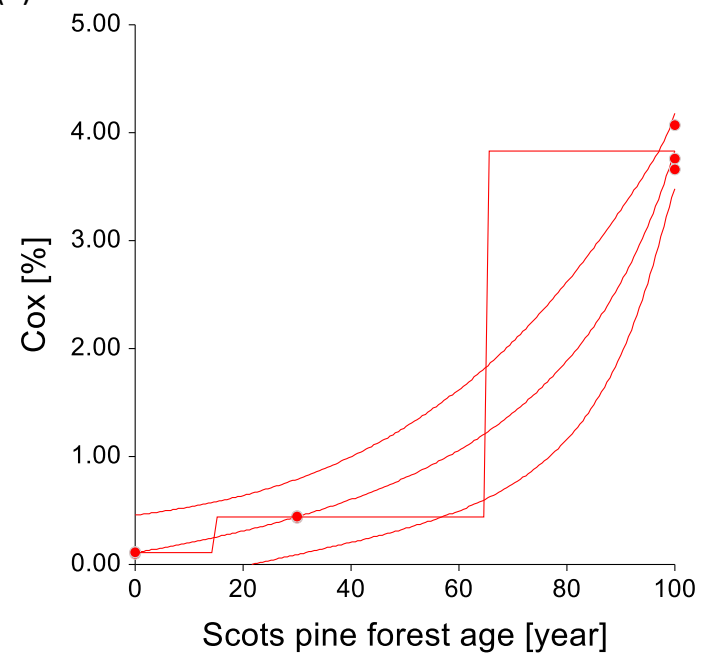

\begin{tabular}{|l|l|l|l|}
\hline \multicolumn{4}{|c|}{$\mathrm{C}_{\mathrm{ox}}=\left(\mathrm{A}+\mathrm{B}^{*}(\mathrm{x})\right) /\left(1+\mathrm{C}^{*}(\mathrm{x})\right)$} \\
\hline $\mathbf{R}^{\mathbf{2}}$ & $\mathbf{A}$ & $\mathbf{B}$ & $\mathbf{C}$ \\
\hline 0.996 & 0.109 & 0.008 & -0.008 \\
\hline
\end{tabular}

(c)

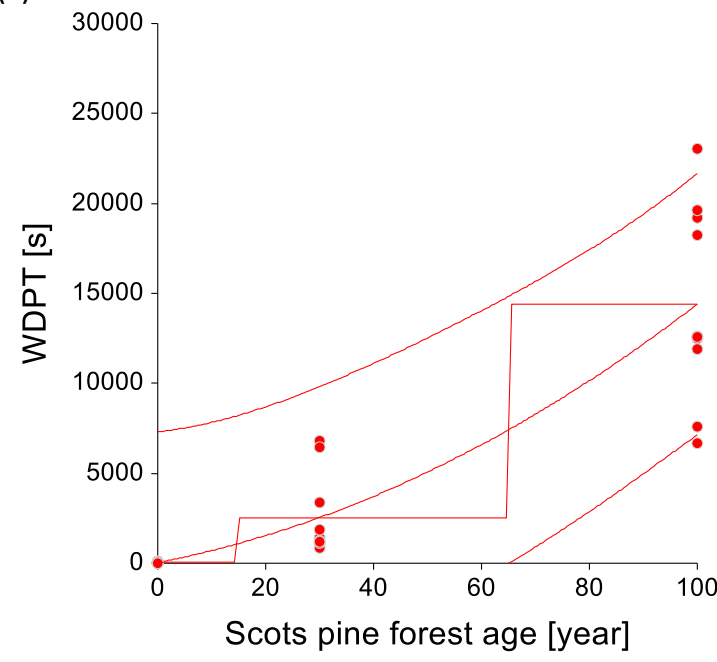

\begin{tabular}{|l|l|l|l|}
\hline \multicolumn{4}{|c|}{ WDPT $=A+B^{*}(x)+C^{*}(x)^{\wedge} 2$} \\
\hline $\mathbf{R}^{2}$ & A & B & C \\
\hline 0.792 & 44.0 & 57.5 & 0.860 \\
\hline
\end{tabular}

(b)

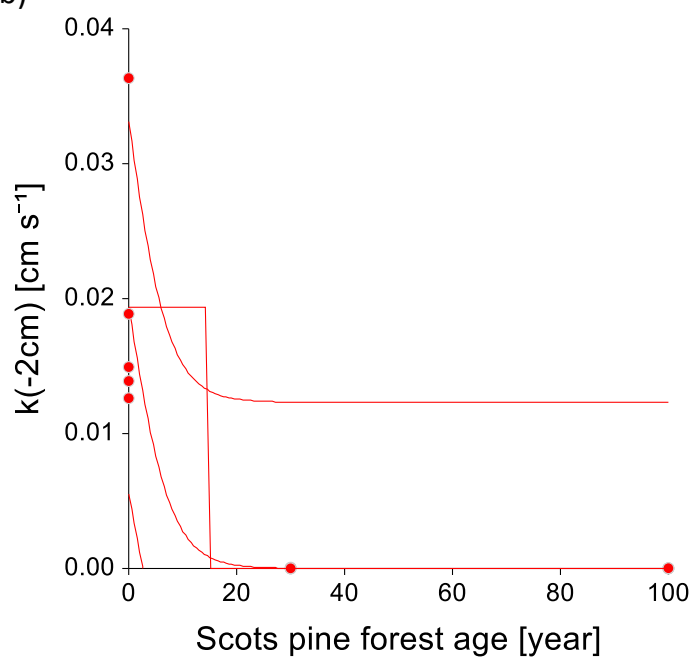

\begin{tabular}{|l|l|l|l|}
\hline \multicolumn{4}{|c|}{$\mathrm{k}(-2 \mathrm{~cm})=\mathrm{A} /\left(1+\mathrm{B}^{*} \operatorname{EXP}\left\{-\mathrm{C}^{*}(\mathrm{x})\right\}\right)$} \\
\hline $\mathbf{R}^{\mathbf{2}}$ & $\mathbf{A}$ & $\mathbf{B}$ & $\mathbf{C}$ \\
\hline 0.764 & 0.041 & 1.101 & -0.251 \\
\hline
\end{tabular}

(d)

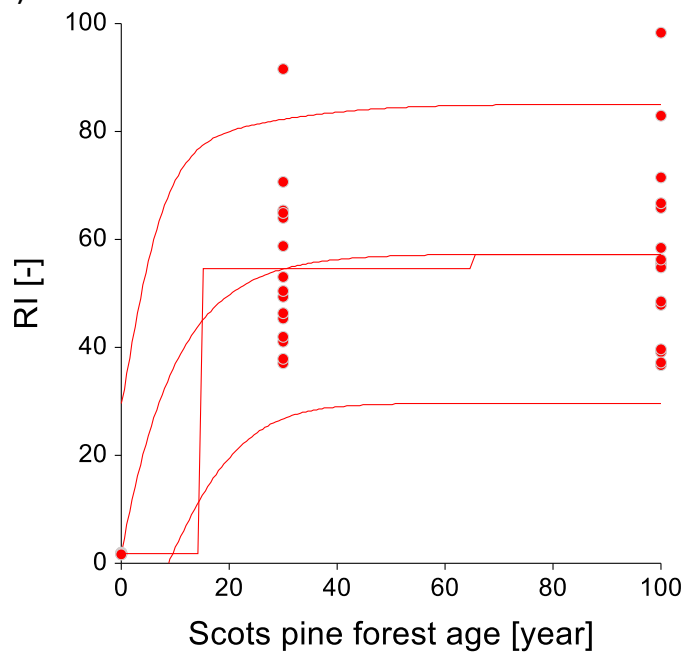

\begin{tabular}{|l|l|l|l|}
\hline \multicolumn{4}{|c|}{$\mathrm{Rl}=\mathrm{A}^{*}\left(1-\operatorname{EXP}\left(-\mathrm{B}^{*}((\mathrm{x})-\mathrm{C})\right)\right)$} \\
\hline $\mathbf{R}^{\mathbf{2}}$ & $\mathbf{A}$ & $\mathbf{B}$ & $\mathbf{C}$ \\
\hline 0.798 & 57.301 & 0.010 & -0.321 \\
\hline
\end{tabular}

Fig. 5. The relationships of $\mathrm{C}_{\mathrm{ox}}(\mathrm{a})$, hydraulic conductivity $k(-2 \mathrm{~cm})(\mathrm{b})$, water drop penetration time WDPT (c), and repellency index RI (d) vs. Scots pine forest age in sandy soil in Borská nížina lowland (southwestern Slovakia). (Middle red line - regression curve, red area the upper and lower boundaries of a prediction interval at a specific value of $\mathrm{x}$, red dots - measured values).

\section{CONCLUSIONS}

This study has shown that sand fraction, $\mathrm{pH}$, and soil hydrophysical properties (saturated and unsaturated hydraulic conductivity, water and ethanol sorptivity) are decreasing with increasing age of Scots pine plantations, while soil organic carbon content and water repellency properties (water drop penetration time and repellency index) show opposite pattern in sandy soil in Borská nížina lowland (southwestern Slovakia). It was found that soil organic carbon content varies most significantly with plantation age, and relative differences in particle size distribution and $\mathrm{pH}$ were smaller than the relative differ- ence in soil organic carbon content. The PF3 site differs the most from the other two sites, especially in soil organic carbon content and in the content of sand fraction. It can be attributed to the older age of the plantation, which represents a more advanced stage of succession accompanied by an accumulation of soil organic matter. The differences in soil hydrophysical properties were attributed to the soil organic carbon content and vegetation induced soil water repellency (pine needles at PF2 site and grass cover/pine needles at PF3 site). As the ethanol sorptivity is a measure of soil pore size only, its decrease with the Scots pine plantation age resulted from an increase in soil pore size in time. To expand gained knowledge, further re- 
search is needed, especially on the effect of forest age and induced soil water repellency (as a dynamic property) on the retention capacity of sandy soil.

Acknowledgements. This contribution was supported by the Scientific Grant Agency VEGA Project No. 2/0150/20 and Project EIG JC2019-074 "Soil Eco-Technology to Recover Water Storage in disturbed Forests". This publication was supported by the Operational program Integrated Infrastructure within the project: Sustainable smart farming systems taking into account the future challenges $313011 \mathrm{~W} 112$, cofinanced by the European Regional Development Fund.

\section{REFERENCES}

Achilles, F., Tischer, A., Bernhardt-Romermann, M., Heinze, M., Reinhardt, F., Makeschin, F., Michalzik, B., 2021. European beech leads to more bioactive humus forms but stronger mineral soil acidification as Norway spruce and Scots pine - Results of a repeated site assessment after 63 and 82 years of forest conversion in Central Germany. Forest Ecology and Management, 483, Article Number: 118769. DOI: $10.1016 /$ j.foreco.2020.118769

Ahtikoski, A., Alenius, V., Makitalo, K., 2010. Scots pine stand establishment with special emphasis on uncertainty and costeffectiveness, the case of northern Finland. New Forests, 40, 69-84.

Alagna, V., Iovino, M., Bagarello, V., Mataix-Solera, J., Lichner, L., 2017. Application of minidisk infiltrometer to estimate water repellency in Mediterranean pine forest soils. Journal of Hydrology and Hydromechanics, 65, 254-263.

Alagna, V., Iovino, M., Bagarello, V., Mataix-Solera, J., Lichner, L., 2019. Alternative analysis of transient infiltration experiment to estimate soil water repellency. Hydrological Processes, 33, 661-674.

Benito, E., Varela, E., Rodríguez-Alleres, M., 2019. Persistence of water repellency in coarse-textured soils under various types of forests in NW Spain. Journal of Hydrology and Hydromechanics, 67, 2, 129-134.

Bisdom, E.B.A., Dekker, L.W., Schoute, J.F.T., 1993. Water repellency of sieve fractions from sandy soils and relationships with organic material and soil structure. Geoderma, 56, 105-118.

Bolte, A., Villanueva, I., 2005. Interspecific competition impacts on the morphology and distribution of fine roots in European beech (Fagus sylvatica L.) and Norway spruce (Picea abies (L.) Karst.). Eur. J. Forest Res., 125, 15-26. https://doi.org/10.1007/s10342-005-0075-5

Buczko, U., Bens, O., Fischer, H., Hüttl, R.F., 2002. Water repellency in sandy luvisols under different forest transformation stages in northeast Germany. Geoderma, 109, 1-18.

Buczko, U., Bens, O., Hüttl, R.F., 2005. Variability of soil water repellency in sandy forest soils with different stand structure under Scots pine (Pinus sylvestris) and beech (Fagus sylvatica). Geoderma, 126, 3-4, 317-336.

Cesarano, G., Incerti, G., Bonanomi, G., 2016. The influence of plant litter on soil water repellency: insight from ${ }^{13} \mathrm{C}$ NMR spectroscopy. PLoS One, 11, 3, Article Number: e0152565.

Clothier, B.E., Vogeler, I., Magesan, G.N., 2000. The breakdown of water repellency and solute transport through a hydrophobic soil. Journal of Hydrology, 231-232, 255-264.

Decagon, 2007. Minidisk Infiltrometer User's Manual. Decagon Devices, Inc., Pullman.

Diehl, D., 2013. Soil water repellency: Dynamics of heterogeneous surfaces. Colloids and Surfaces A:
Physicochem. Eng. Aspects, 432, 8-18.

Doerr, S.H., 1998. On standardizing the "Water Drop Penetration Time" and the "Molarity of an Ethanol Droplet" techniques to classify soil hydrophobicity: a case study using medium textured soils. Earth Surface Processes and Landforms, 23, 663-668.

Doerr, S.H., Shakesby, R.A., Walsh, R.P.D., 2000. Soil water repellency: its causes, characteristics and hydrogeomorphological significance. Earth-Science Reviews, 51, 33-65.

Fér, M., Leue, M., Kodešová, R., Gerke, H.H., Ellerbrock, R.H., 2016. Droplet infiltration dynamics and soil wettability related to soil organic matter of soil aggregate coatings. Journal of Hydrology and Hydromechanics, 64, 111-120.

Goebel, M.-O., Bachmann, J., Woche, S.K., Fischer, W.R., 2005. Soil wettability, aggregate stability, and the decomposition of soil organic matter. Geoderma, 128, 80-93.

Hallett, P.D., Young, I.M., 1999. Changes to water repellence of soil aggregates caused by substrate-induced microbial activity. European Journal of Soil Science, 50, 35-40.

Hewelke, E., Oktaba, L., Gozdowski, D., Kondras, M., Olejniczak, I., Górska, E.B., 2018. Intensity and persistence of soil water repellency in pine forest soil in a temperate continental climate under drought conditions. Water, 10, 9, Article Number: 1121.

Hrabovský, A., Dlapa, P., Cerda, A., Kollár, J., 2020. The impacts of vineyard afforestation on soil properties, water repellency and near-saturated infiltration in the Little Carpathians mountains. Water, 12, Article Number: 2550.

Iovino, M., Pekárová, P., Hallett, P.D., Pekár, J., Lichner, L., Mataix-Solera, J., Alagna, V., Walsh, R., Raffan, A., Schacht, K., Rodný, M., 2018. Extent and persistence of soil water repellency induced by pines in different geographic regions. Journal of Hydrology and Hydromechanics, 66, 360-368.

ISO 10390, 2005. Soil quality. Determination of pH. International Organization of Standardization, Geneva. (https://www.iso.org/standard/40879.html)

ISO 10693, 1995. Soil quality. Determination of carbonate content. Volumetric method. International Organization of Standardization, Geneva. (https://www.iso.org/standard/18781.html)

ISO 10694, 1995. Soil quality. Determination of organic and total carbon after dry combustion (elementary analysis). International Organization of Standardization, Geneva. (https://www.iso.org/standard/18782.html)

ISO 11277, 2009. Soil quality. Determination of particle size distribution in mineral soil material. Method by sieving and sedimentation. International Organization of Standardization, Geneva. (https://www.iso.org/standard/54151.html)

Jandl, R., Lindner, M., Vesterdal, L., Bauwens, B., Baritz, R., Hagedorn, F., Johnson, D.W., Minkkinen, K., Byrne, K.A., 2007. How strongly can forest management influence soil carbon sequestration? Geoderma, 137, 3-4, 253-268.

Kalivodová, E., Kubíček, F., Bedrna, Z., Kalivoda, H., Gavlas, V., Kollár, J., Gajdoš, P., Štepanovičová, O., 2002. Sand dunes of Slovakia. Luka-Press, Bratislava, 60 p. (In Slovak.)

Kottek, M., Grieser, J., Beck, C., Rudolf, B., Rubel, F., 2006. World map of the Köppen-Geiger climate classification updated. Meteorologische Zeitschrift, 15, 259-263.

Krippel, E., 1965. Post-glacial development of forests in the Záhorská nížina lowland. Biol. práce, Bratislava, 11, 3, 1100. (In Slovak.)

Leelamanie, D.A.L., Nishiwaki, J., 2019. Water repellency in Japanese coniferous forest soils as affected by drying temperature and moisture. Biologia, 74, 127-137. 
Lichner, L., Babejová, N., Dekker, L.W., 2002. Effects of kaolinite and drying temperature on the persistence of soil water repellency induced by humic acids. Rostlinná Výroba, 48, 203-207.

Lichner, L., Capuliak, J., Zhukova, N., Holko, L., Czachor, H., Kollár, J., 2013. Pines influence hydrophysical parameters and water flow in a sandy soil. Biologia, 68, 1104-1108.

Lichner, L., Felde, V.J.M.N.L., Büdel, B., Leue, M., Gerke, H.H., Ehlerbrock, R.H., Kollár, J., Rodný, M., Šurda, P., Fodor, N., Sándor, R., 2018. Effect of vegetation and its succession on water repellency in sandy soils. Ecohydrology, 11, 6, Article Number: UNSP e1991.

Lichner, L., Alagna, V., Iovino, M., Laudicina, V.A., Novák, V., 2020a. Evaporation from soils of different texture covered by layers of water repellent and wettable soils. Biologia, 75, 6, 865-872.

Lichner, L., Iovino, M., Šurda, P., Nagy, V., Zvala, A., Kollár, J., Pecho, J., Píš, V., Sepehrnia, N., Sándor, R., 2020 b. Impact of secondary succession in abandoned fields on some properties of acidic sandy soils. Journal of Hydrology and Hydromechanics, 68, 1, 12-18.

Löf, M., Rydberg, D., Bolte, A., 2006. Mounding site preparation for forest restoration: Survival and growth responses in Quercus robur L. seedlings. For. Ecol. Manage., 232, 1-3, 19-25.

Löf, M., Dey, D.C., Navarro, R.M., Jacobs, D.F., 2012. Mechanical site preparation for forest restoration. New Forests, 43, 825-848.

Luoranen, J., Rikala, R., 2013. Field performance of Scots pine (Pinus sylvestris L.) seedlings planted in disc trenched or mounded sites over an extended planting season. New Forests, 44, 147-162.

Marhold, K., Hindák, F., 1998. Checklist of Nonvascular and Vascular Plants of Slovakia. Veda, Bratislava, 687 p. (In Slovak.)

McKissock, I., Walker, E.L., Gilkes, R.J., Carter, D.J., 2000. The influence of clay type on reduction of water repellency by applied clays: a review of some West Australian work. Journal of Hydrology, 231-232, 323-332.

NCSS 12 Statistical Software, 2018. NCSS, LLC. Kaysville, Utah, USA, ncss.com/software/ncss.

Pekárová, P., Pekár, J., Lichner, L., 2015. A new method for estimating soil water repellency index. Biologia, 70, 14501455.

Piyaruwan, H.I.G.S., Jayasinghe, P.K.S.C., Leelamanie, D.A.L., 2020. Water repellency in eucalyptus and pine plantation forest soils and its relation to groundwater levels estimated with multi-temporal modeling. Journal of Hydrology and Hydromechanics, 68, 4, 382-391.

Reynolds, W.D., Elrick, D.E., Youngs, E.G., Amoozegar, A., Booltink, H.W.G., Bouma, J., 2002. Saturated and fieldsaturated water flow parameters. In: Dane, J.H., Topp, G.C. (Eds.): Methods of Soil Analysis, Part 4. Soil Science Society of America, Inc., Madison, pp. 797-878.
Roper, M.M., 2005. Managing soils to enhance the potential for bioremediation of water repellency. Australian Journal of Soil Research, 43, 803-810.

Roper, M.M., 2006. Potential for remediation of water repellent soils by inoculation with wax-degrading bacteria in southwestern Australia. Biologia, 61, Suppl. 19, S358-S362.

Rye, C.F., Smettem, K.R.J., 2017. The effect of water repellent soil surface layers on preferential flow and bare soil evaporation. Geoderma, 289, 142-149.

Sarvaš, M., Tučeková, A., Takáčová, E., Chválová, K., Lengyelová, A., Varínsky, J., Longauerová, V., Sušková, M., 2007. Forest establishment in changing ecological conditions. Národné lesnícke centrum, Zvolen, 107 p. (In Slovak.)

Soil Survey Division Staff, 1993. Soil Survey Manual. Soil Conservation Service. U.S. Department of Agriculture Handbook, $18 \mathrm{p}$.

Šomšák, L., Šimonovič, V., Kollár J., 2003. Phytocoenoses of pine forests in the central part of the Záhorská nížina Lowland. Biologia, Bratislava, 59, 101-113.

Šurda, P., Lichner, L., Nagy, V., Kollár, J., Iovino, M., Horel, Á., 2015. Effects of vegetation at different succession stages on soil properties and water flow in sandy soil. Biologia, 70, $11,1474-1479$.

Sutton, R.F., 1993. Mounding site preparation: A review of European and North American experience. New Forests, 7, 151-192.

Tinebra, I., Alagna, V., Iovino, M., Bagarello, V., 2019. Comparing different application procedures of the water drop penetration time test to assess soil water repellency in a fire affected Sicilian area. Catena, 177, 41-48.

Turfan, N., Alay, M., Sariyildiz, T., 2018. Effect of tree age on chemical compounds of ancient Anatolian black pine (Pinus nigra subsp. pallasiana) needles in Northwest Turkey. iForest, 11, 406-410.

Villarreal, R., Lozano, L.A., Melani, E.M., Salazar, M.P., Otero, M.F., Soracco, C.G., 2019. Diffusivity and sorptivity determination at different soil water contents from horizontal infiltration. Geoderma, 338, 88-96.

WRB, 2014. World Reference Base for Soil Resources 2014. World Soil Resources Reports No. 106. Rome, 192 p.

Zavala, L.M., González, F.A., Jordán, A., 2009. Intensity and persistence of water repellencyin relation to vegetation types and soil parameters in Mediterranean SW Spain. Geoderma, $152,361-374$.

Zema, D.A., Plaza-Alvarez, P.A., Xu, X.Z., Carra, B.G., LucasBorja, M.E., 2021. Influence of forest stand age on soil water repellency and hydraulic conductivity in the Mediterranean environment. Science of the Total Environment, 753, Article Number: 142006.

Zhang, R., 1997. Determination of soil sorptivity and hydraulic conductivity from the disk infiltrometer. Soil Science Society of America Journal, 61, 1024-1030.

Received 25 March 2021 Accepted 12 May 2021 